\title{
ウラピジル徐放性カプセルの簡易懸濁法実施による溶出変化
}

\author{
櫻田＼cjkstart渉, 下山哲哉, 伊藤邦彦, 小林道也* \\ 北海道医療大学薬学部薬剤学講座 (臨床薬剤学)

\section{Changes in Elution of Urapidil Sustained Release Capsules Prepared by Simple Suspension Method}

\author{
Wataru Sakurada, Tetsuya Shimoyama, Kunihiko Itoh and Michiya Kobayashi* \\ Division of Pharmaceutics (Clinical Pharmaceutics), School of Pharmaceutical Sciences, \\ Health Sciences University of Hokkaido \\ $\left[\begin{array}{l}\text { Received December 25, } 2015 \\ \text { Accepted February 12, } 2016\end{array}\right]$
}

EBRANTIL $^{\circledR}$ Capsules are a drug product of urapidil, an alpha-1 adrenergic receptor antagonist, in the form of enteric/sustained-release granule filled capsules. This product can be administered as a solution prepared by the simple suspension method (SSM) to patients with gastrostomy through tubes; however, there is no information on the elution behavior of the drug administered by SSM.

In this study, one EBRANTIL ${ }^{\circledR}$ Capsules $15 \mathrm{mg}$ was put in $20 \mathrm{~mL}$ of purified water or Japanese Pharmacopoeia (JP) 1st fluid for the dissolution test $\left(\mathrm{pH} \mathrm{1.2)}\right.$ of 55 and $37^{\circ} \mathrm{C}$. The test container was left for 10 minutes, then the content was suspended. The dissolution test was carried out in JP 1st fluid.

The elution of urapidil from EBRANTIL ${ }^{\circledR}$ Capsules untreated by SSM was $30 \%$ or less in 60 minutes. Ninety percent or greater of urapidil eluted in 30 minutes treated with water of $55^{\circ} \mathrm{C}$. The elution rate of urapidil treated with water of $37^{\circ} \mathrm{C}$ was relatively slower than that; however, $60 \%$ or greater urapidil eluted in 60 minutes. The elution behavior of urapidil from the capsule treated with JP 1st fluid was almost the same as that of the untreated EBRANTIL ${ }^{\circledR}$ Capsules. These data suggest that the granules in the capsules were slightly dissolved in JP 1st fluid, but they dissolved immediately in water of 55 and $37^{\circ} \mathrm{C}$.

In conclusion, EBRANTIL ${ }^{\circledR}$ Capsules should not be administered by SSM to avoid lowering blood pressure when treating patients.

Key words — simple suspension method, sustained-release granules, enteric-coated granule, urapidil, dissolution test

\section{緒 言}

近年，嚥下困難な患者に対して，胃ろうを造設 して栄養剤や医薬品をチューブを介して投与する ケースが増えている。胃ろう造設患者に対する医 薬品の投与方法としては, 特殊な器具や手技を必 要としない簡易懸濁法 ${ }^{1)}$ が開発され, 多くの医療 機関や患者居宅において実施されている. ${ }^{2-5)}$ 簡易 懸濁法とは，通常，錠剤やカプセル剂等の固形製 剂を $55^{\circ} \mathrm{C}$ の温湯に添加し, 10 分間放置した後に混
和して懸濁状態としてシリンジ等に充てんし, 胃 ろうチューブを介して患者に投与する方法である. 医薬品ごとの簡易懸濁法実施の可否については, 倉田らによりデータベースが作成されており, ${ }^{1}$ 臨床において活用されている。しかしながら，そ の判断基準の多くはチューブの通過性などの物理 的な特徴であり，簡易懸濁後の医薬品からの薬物 溶出性についてはほとんど言及されていない.

我々はこれまでに，オレンジブックや医療用医 薬品インタビューフォーム等に公表されている医

\footnotetext{
*\%061-0293 北海道石狩郡当別町金沢1757
} 
薬品の溶出試験結果より，簡易懸濁法を実施した 際の薬物の溶出性への影響をある程度予測できる ことを報告した。 ${ }^{6}$ すなわち，溶出試験において 10 分までの溶出率は $50 \%$ 以下であるが， 60 分以 降ではほぼ完全に溶出するような「穏やかに溶出 する医薬品」は, 簡易懸濁法実施により初期の薬 物溶出が著しく上昇することを見出した。 また, 10 分に扔いてほとんど溶出が完了する「速やか に溶出する医薬品」や，特殊な製剂学的工夫を施 していないにもかかわらず非常に溶出の遅い医薬 品については, 簡易懸濁法実施により溶出率は有 意に増加するものの，その程度は小さいことを明 らかにした。

一方，簡易懸濁法実施の可否についてのデータ ベース ${ }^{1)}$ では，即放性製郕のみならず，徐放性製 剂や腸溶性製剂の簡易懸濁法実施の可否について もまとめられている. 多くの徐放性・腸溶性製剤に 関しては，簡易懸濁法の実施により製剤学的特性 が失われ，薬物の体内動態や胃内での安定性が変 化する可能性があるため簡易懸濁法不可とされて いるが，一部の医薬品については可能とされてい るものもある．本態性高血圧や前立腺肥大に伴う 排尿障害治療薬であるエブランチル®カプセルは, $\alpha_{1}$ 受容体遮断薬であるウラピジルを徐放性顆粒 として充てんしたカプセル剤（http://www.info. pmda.go.jp/downfiles/ph/PDF/200022_2149020N 1031_2_04.pdf，2015 年 12 月 22 日）であるが, $55^{\circ} \mathrm{C}$ の温湯で 10 分間懸濁することで簡易懸濁法 の適用可とされている. ${ }^{1)}$ しかしながら，エブラ ンチル®カプセルの簡易懸濁法実施の可否の判断 に, 実際の溶出試験を行って考察されていない.

そこで本研究では，エブランチル®カプセルの 簡易懸濁法実施による薬物溶出性への影響を明ら かにするとともに，顆粒表面の変化を電子顕微鏡 にて測定することで, 本剤の簡易懸濁法実施の適 切性について考察したので報告する.

\section{方 法}

\section{1. 試薬}

エブランチル®カプセル $15 \mathrm{mg}$ は科研製薬(株) （東京）から購入した（Lot H45680）。 ウラピジル
は LKT Laboratories, Inc (St Paul, MN, USA) から 購入した。精製水は, NANOpure ${ }^{\circledR}$ Diamond $^{\text {TM }}$ (Thermo Fisher Scientific Inc, Waltham, MA, USA) により処理した超純水（比抵抗：18.2 $\mathrm{M} \Omega \cdot \mathrm{cm}$ 以 上）を用いた。その他の試薬類はすべて特級若し くはHPLC用を用いた。

\section{2. 簡易懸濁法}

簡易懸濁法は, 倉田らの方法 ${ }^{1,6)}$ に準拠して行っ た. すなわち, $55^{\circ} \mathrm{C}$ に温めた $20 \mathrm{~mL}$ の精製水の入っ たディスポーザブルシリンジ（テルモ(株), 東京) に薬荗を入れた。これを 10 分間室温で放置し, 15 回転倒混和した。また同様の手法により, $55^{\circ} \mathrm{C}$ の第 16 改正日本薬局方溶出試験第 1 液 $(\mathrm{pH}$ 1.2. 以下，第 1 液), $37^{\circ} \mathrm{C}$ の精製水並びに第 1 液を用い て10 分間の室温放置並びに転倒混和を行った。

\section{3. 溶出試験}

薬物の溶出試験は, 第 16 改正日本薬局方に従っ てパドル法（DT600, Erweka GmbH, Heusenstamm, Germany）で行った。 ${ }^{6}$ すなわち, 溶出試験装置 のベッセル内に $37 \pm 0.5^{\circ} \mathrm{C}$ に温めた溶出試験第 1 液 $900 \mathrm{~mL}$ を入れ, 転倒混和操作を施した懸濁液 $20 \mathrm{~mL}$ をベッセル内に添加し, パドル回転速度は $50 \mathrm{rpm}$ で実験を行った。なお，精製水あるいは 第 1 液を用いた条件で, ベッセル内の $\mathrm{pH}$ はほと んど変化しないことを確認した. 試験を開始後, 5 , 10，15，30，45，60 分において $1 \mathrm{~mL}$ の溶出試験 液をメンブランフィルター（Millex ${ }^{\circledR}-\mathrm{LH} \quad 0.45 \mu \mathrm{m}$, Merck Millipore Co, Darmstadt, Germany）を通し て採取し, 同じ量の第 1 液をベッセル内に戻した. ろ液は溶出試験第 2 液（pH 6.8）で 10 倍に希釈 した後，HPLCで測定した，簡易懸濁法非実施群 は, 矁濁操作を行わずにエブランチル®カプセル をそのまま溶出試験容器に添加し, 同時に $55^{\circ} \mathrm{C}$ の精製水 $20 \mathrm{~mL}$ を室温で 10 分放置したものを ベッセル内に加えて実験を行った。

\section{HPLC 条件}

島津 HPLC システム（LC-20AD ポンプ，SPD20A UV 検出器, SIL-20A オートサンプラー, CTO-20A カラムオーブン, DGU-20A3 デガッサー, 
C-R8A インテグレーター, (株) 島津製作所, 京都) を使用した。カラムは Inertsil ${ }^{\circledR}$ ODS $(4.6 \mathrm{~mm} \times$ $150 \mathrm{~mm}, 5 \mu \mathrm{m}$ ，ジーエルサイエンス(株)，東京） を用いた。流速は $1.0 \mathrm{~mL} / \mathrm{min}$, カラム温度 $55^{\circ} \mathrm{C}$ で行った。 ウラピジルの検出波長は $269 \mathrm{~nm}$ ，移動 相は $\mathrm{CH}_{3} \mathrm{CN} ： 50 \mathrm{mM} \mathrm{KH}_{2} \mathrm{PO}_{4}=80 ： 20$ とした．検 量線には, 通常, $0.5 〜 2.0 \mu \mathrm{g} / \mathrm{mL}$ の標準液を用いた.

\section{5. 走査型電子顕微鏡法}

エブランチル®カプセルを $55^{\circ} \mathrm{C}$ の精製水ない し第 1 液 $(20 \mathrm{~mL})$ に添加して 10 分間放置した後, 転倒混和操作した懸濁液を液体窒素で瞬間凍結 し, 粉挽して顆粒残渣を取り出し, 真空ポンプ （RV8，エドワーズ(株)，千葉）を用いて 24 時間 凍結乾燥した。 その後, イオンコーター（IB-3,

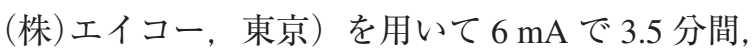
金イオンコーティングしたものを走査型電子顕微 鏡（S-3500N，(株) 日立八イテクノロジーズ, 東京) で観察した。

\section{6. デー夕解析}

すべてのデー夕は, 平均 \pm 標準偏差で示した. 各条件における各時間の溶出率の違いについては Tukey-Kramer 検定を行い, $P<0.05$ をもって有意 な差とした，統計ソフトには，エクセル統計 2008（(株)社会情報サービス，東京）を用いた。

\section{結果}

\section{1. 簡易懸濁法実施によるウラピジルの溶出}

図 1 に，エブランチル®カプセルを用いて簡易 懸濁法を実施後のウラピジルの溶出挙動を示し た。簡易懸濁法を実施しなかった場合，すなわち エブランチル®カプセルをそのまま溶出試験装置 のベッセル内に入れた場合のウラピジルの溶出は 遅く，溶出率は 10 分で $4.4 \pm 1.0 \% ， 30$ 分で 15.2 土2.7\%, 60 分で $28.3 \pm 1.1 \%$ であた（図 1A）. 一方， $55^{\circ} \mathrm{C}$ の精製水を用いて簡易懸濁法を実施し た際の溶出率は, 10 分で $52.0 \pm 4.5,30$ 分で $90.4 \pm 6.4 \%$ と著しい溶出促進が認められ，45 分 以降はほぼ100\%が溶出した。

この溶出促進の原因が, 温度に起因するものか, もしくは懸濁液の $\mathrm{pH}$ に起因するものかを明らか にするために， $37^{\circ} \mathrm{C} の$ 精製水を用いて簡易懸濁法 と同じ操作を行ったもの $\left(37^{\circ} \mathrm{C}\right.$ 精製水懸濁群) と, 精製水ではなく第 1 液を用いた場合 $\left(55^{\circ} \mathrm{C}\right.$ 第 1 液懸濁群, $37^{\circ} \mathrm{C}$ 第 1 液懸濁群) との比較を行った. $37^{\circ} \mathrm{C}$ 精製水懸濁群では，10 分で $20.5 \pm 4.9 \% ， 30$ 分で $45.1 \pm 7.9 \%, 60$ 分では $66.1 \pm 7.6 \%$ と, $55^{\circ} \mathrm{C}$ の条件に比べ溶出率は低下したものの，簡易 懸濁法非実施時に比べて溶出率は有意に増大し た。また， $55^{\circ} \mathrm{C}$ の精製水を用いた場合の簡易懸濁 法完了時の懸濁液の $\mathrm{pH}$ は $5.92 \pm 0.16, \quad 37^{\circ} \mathrm{C}$ 条件
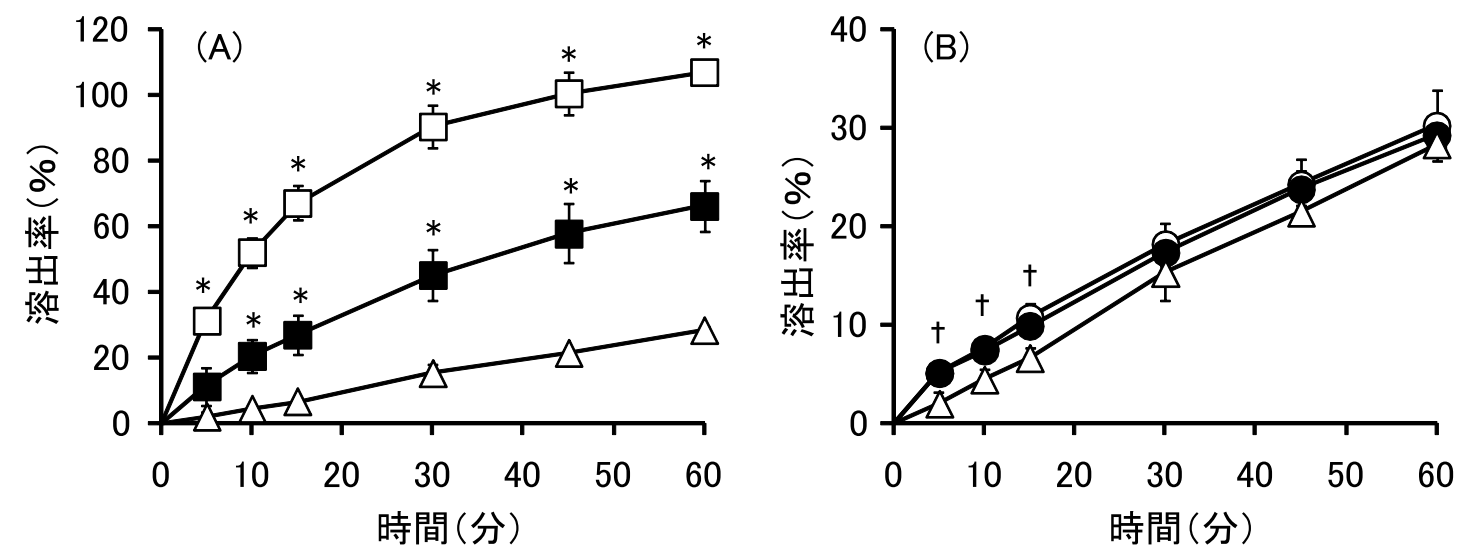

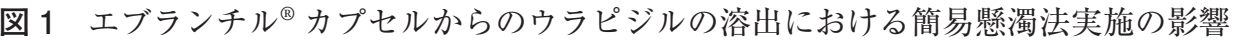

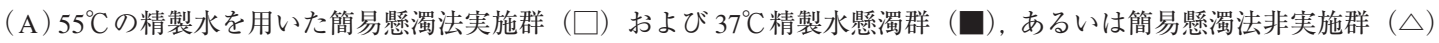
に打ける溶出挙動を示す。（B $55^{\circ} \mathrm{C}$ 第 1 液懸濁群 $(\bigcirc), 37^{\circ} \mathrm{C}$ 第 1 液懸濁群 $($ ) あるいは簡易懸濁法非実施群 $(\triangle)$ における溶出挙動を示す。結果はすべて平均 \pm 標準偏差 $(n=4)$ で表した。 *簡易懸濁法非実施群に対して $P<0.05$. †簡易懸濁法非実施群に対して, $55^{\circ} \mathrm{C}$ と $37^{\circ} \mathrm{C}$ の条件いずれの值も $P<0.05$. 
では $5.97 \pm 0.02$ と，ほとんど違いは認められな かった.

次に, $55^{\circ} \mathrm{C}$ あるいは $37^{\circ} \mathrm{C}$ 第 1 液懸濁群におけ るウラピジルの溶出挙動を測定した. その結果, 図 1Bに示すように溶出試験開始 5～15 分におけ る溶出率は $55^{\circ} \mathrm{C}$ 並びに $37^{\circ} \mathrm{C}$ 条件ともに非実施時 に比べて有意な溶出率の上昇が認められたが，そ の程度は非常に小さいものであった。また，30 分以降の溶出率は 3 群間で有意な差は認められな かった.

\section{2. 電子顕微鏡による顆粒表面の観察}

次に，簡易懸濁法実施群あるいは $55^{\circ} \mathrm{C}$ 第 1 液 懸濁群の顆粒表面の状態を電子顕微鏡で観察し た．図2Aに示すように，簡易懸濁法を実施して いない乾燥した顆粒の表面は, 比較的滑らかな状 態であった。一方，簡易懸濁法を実施した場合に は，表面の一部に腸溶性高分子の溶解によって形 成したと考えられる細孔が観察された（図 2B）. これに対し, $55^{\circ} \mathrm{C}$ 第 1 液懸濁群の顆粒表面は滑ら かであることが観察された（図 2C）.

\section{考察}

簡易懸濁法は，固形製剤を粉砕して経管的に投 与することに比べて, 粉砕後の安定性や配合変化 の問題を回避できること, ${ }^{7)}$ 並びに粉砕調剂時の 医薬品のロスを防ぐことができる ${ }^{8)}$ などのメリッ トがある。一方，通常は主に胃内で進む医薬品の 崩壊過程を省略してしまうため, 薬物の溶出性に 影響を与えるおそれがある。我々はこれまでに, 水に難溶解性の医薬品について簡易懸濁法を実施 した場合の薬物の溶解性について検討し, フェニ トインやプランルカストは簡易懸濁液中では飽和 溶解度まで溶解していることを報告した。? ${ }^{9}$ また， 10 種類の医薬品を用いて簡易懸濁法実施による 溶出試験結果に与える影響について検討したとこ ろ, 比較的穏やかに溶出する医薬品ほど簡易懸濁 法実施により溶出が速まることを明らかにした。 ${ }^{6}$ これらの結果は，簡易懸濁法を実施することで， 一部の医薬品は胃内での溶解性や溶出性が高ま り, 薬物の吸収が速まるおそれのあることを示唆 するものであった。一方，腸溶性製剂や徐放性製
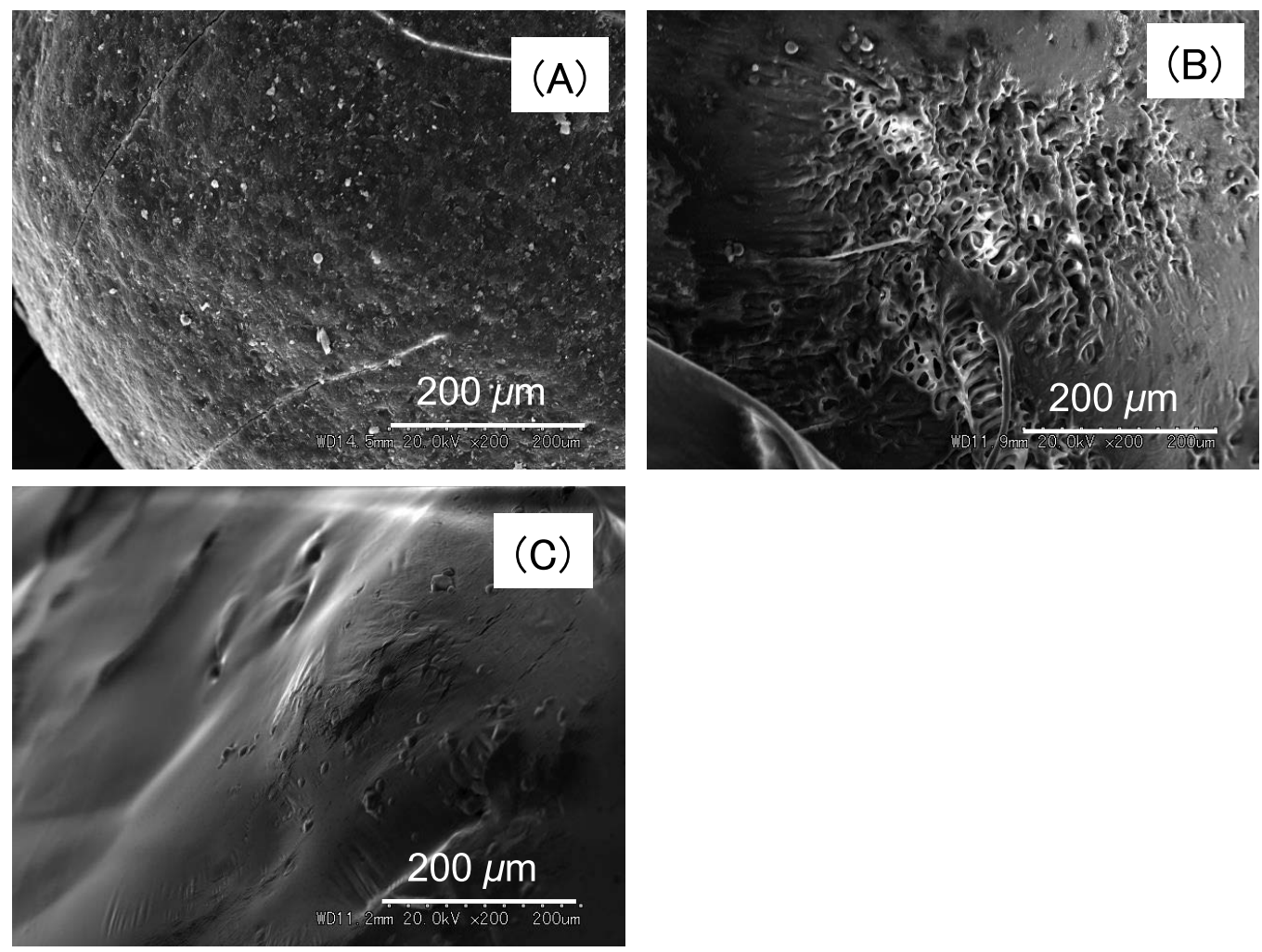

図 2 無処理 $(\mathrm{A})$ ，あるいは $55^{\circ} \mathrm{C}$ の精製水（B）または第 1 液（C）で 10 分間処理したエブ ランチル カ カプセル内の顆粒の電子顕微鏡写真 (200 倍) 
剤のように，製剤学的工夫により薬物の放出が制 御されている医薬品については，その多くが簡易 懸濁法の実施が不可とされている. ${ }^{11}$ 例えば， 口 ンタブ型のニフェジピン徐放錠（アダラート ${ }^{\circledR} \mathrm{CR}$ 錠）は体内動態の恋動の観点から簡易懸濁法の実 施は不可とされている。 一方，テオフィリンの徐 放錠であるテオロング® 錠は, $50 \mathrm{mg}$ 錠は適用可 とされているが, $100 \mathrm{mg}$ や $200 \mathrm{mg}$ 錠は不適とさ れ，また同じテオフィリン徐放性製剤であるテオ ドール®やユニフィル®は不適とされている。 タ ムスロシンの腸溶性顆粒を口腔内崩壊錠として製 したハルナール ${ }^{\circledR} \mathrm{D}$ は，簡易懸濁時間を 5 分間と することで適用可とされている。このような適用 が可能とされている放出制御型製郕に関して，そ の根拠は胃ろうを介して投与するチューブの通過 性によるものであり，簡易懸濁法実施による薬物 の体内動態変化や溶出試験結果の変動に関する報 告はない，そこで今回，簡易懸濁法の実施が可能 とされているエブランチル®カプセルに着目し, その溶出性に対する影響について検討した。

エブランチル®カプセルは， $\alpha_{1}$ 受容体遮断薬で あるウラピジルを水不溶性ポリマーとアルカリ溶 解性ポリマー（腸溶性ポリマー）によりコーティ ングした徐放性顆粒を，カプセルに充てんした製 剤である（http://ebrantil.jp/FAQ.html，2015 年 12 月 22 日). エブランチル®カプセルの添付文書に 記載されている添加物は, 精製白糖, トゥモロコ シデンプン，ポビドン，ステアリン酸，ヒプロメ ロースフタル酸エステル, エチルセルロース, 乳 糖水和物，ヒドロキシプロピルセルロース，ステ アリン酸マグネシウムであり（http://www.info. pmda.go.jp/downfiles/ph/PDF/200022_2149020 N1031_2_04.pdf, 2015 年 12 月 22 日), 水不溶性 ポリマーとしてエチルセルロースが，腸溶性ポリ マーとしてヒプロメロースフタル酸エステルが使 用されていると考えられる。ヒプロメロースフ夕 ル酸エステルは製品によって異なるが，概ね $\mathrm{pH}$ 5.5 以上になると水に溶解するとされている（http:// www.metolose.jp/pharmaceutical/hpmcp.shtml, 2015年 12 月 22 日)。これらを配合することで, 胃内の 酸性条件下ではほとんど顆粒は溶けず，小腸へ移 行して $\mathrm{pH}$ が5.0〜 5.5 以上になると, ヒプロメロー
スフタル酸エステルの溶解性が高まることで徐放 性が維持されている。しかしながら, 臨床におい て簡易懸濁法を実施する際には $55^{\circ} \mathrm{C}$ の水道水を 用いる場合がほとんどであり，このような条件に おいては腸溶性ポリマーが溶解することが予測さ れる。

本研究ではまず初めに, $55^{\circ} \mathrm{C}$ の精製水を用いて 簡易懸濁法を実施し, エブランチル®カプセルか らのウラピジルの溶出を測定した. 簡易懸濁法非 実施，すなわちエブランチル®カプセルをそのま ま溶出試験装置のベッセル内に入れた場合に比 べ，簡易懸濁法を実施した場合にはウラピジルの 製剤から溶出は著しく促進された（図 1A）。こ の時の懸濁液の $\mathrm{pH}$ はヒプロメロースフタル酸エ ステルが溶解できる $\mathrm{pH} 5.5$ 以上であった。 また, $55^{\circ} \mathrm{C}$ 第 1 液懸濁群におけるウラピジルの溶出は, 開始 15 分間までは有意な溶出促進が認められた ものの，その程度は小さかった（図 1B）。我々は これまでに, 溶出の非常に遅いイブプロフェン錠 やフロセミド錠は，簡易懸濁法を実施することで 初期に溶出促進が認められるものの, その後の溶 出速度は非実施の場合とほほ等しいことを報告し ている. ${ }^{6} 55^{\circ} \mathrm{C}$ 第 1 液懸濁群におけるウラピジル の溶出挙動もこれらの医薬品の特徵とほぼ一致し ていることから, $55^{\circ} \mathrm{C}$ の第 1 液に 10 分間浸し, 次いで行った転倒混和操作の間にウラピジルが一 部溶出し，この溶出分が上乗せされる形となった と考えられる.ささらに，電子顕微鏡による観察よ り， $55^{\circ} \mathrm{C}$ の精製水を用いて簡易懸濁法を実施した 場合には顆粒表面が溶解しているのに対し（図 2B), $55^{\circ} \mathrm{C}$ 第 1 液懸濁群では変化が認められな かった（図 2C）。従って，精製水を用いて簡易 㲘濁法を実施している 10 分の間に, 顆粒の一部 が溶解してウラピジルの放出が高まったものと考

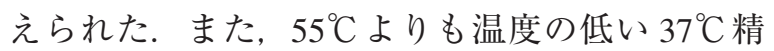
製水懸濁群においても， $55^{\circ} \mathrm{C}$ の条件よりは溶出率 が低いものの, 簡易懸濁法非実施の場合と比べて ウラピジルの溶出の有意な増大が認められた（図 1A).

カプセル剂を服用するのが困難なため脱カプセ ルして服用することは臨床において散見される事 例ではあるが, エブランチル®カプセルはカプセ 
ル自体には腸溶性や徐放性の特性はないことか ら, 脱カプセルによる服用は可能となっている. この場合, ウラピジル徐放性顆粒を水と共に服用 するため，速やかに胃内の酸性状態にさらされ， カプセル剂として服用した場合とほぼ同じ溶出挙 動を示すものと考えられる。しかしながら， $55^{\circ} \mathrm{C}$ の水道水を用いて簡易懸濁法を行った場合には, 簡易懸濁中に腸溶性ポリマーが溶解し，投与した 後の胃内に打ける溶出性が著しく上昇することが 示唆された。 また，簡易懸濁法を $37^{\circ} \mathrm{C}$ の水道水 を用いたとしても，程度の差はあれ溶出性が高ま ることが予想される。これを回避するためには, 第 1 液のような酸性溶液を用いて簡易懸濁法を実 施することが必要となるが，臨床においてそのよ うな作業は現実的ではない。

本研究は，簡易懸濁法を実施することにより， 腸溶性や徐放性高分子を用いた放出制御型製郕の 薬物溶出性は大きく変動することを見出した初め ての報告である．簡易懸濁法実施後のウラピジル の血中濃度推移は検討していないが，徐放性製剂 の放出制御システムを崩壊させることは, 薬物の 吸収速度を促進させ， $\alpha_{1}$ 受容体遮断薬の特性か ら予期せぬ血圧低下を引き起こすことが予想され

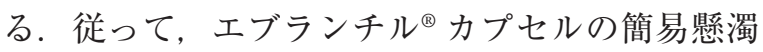
法への適用は不適とすべきであると考える.

\section{謝辞}

本論文を作成にあたり，実験に協力いただいた 斎藤友里子氏に感謝します。

\section{利益相反}

開示すべき利益相反はない.

\section{引用文献}

1）藤島一郎, 倉田なお 久編，“内服薬経管投与ハン ドブック”, 第 3 版, ビほう, 東京, 2015, pp1-54.

2）市東友和, 山浦真弓, 調剤業務効率化に向けた簡 易懸濁法の導入, 医療薬学, 2006, 32, 517-522.

3）西園憲郎, 我妻 仁, 佐々木吉幸, 稲瀬 實, 賀勢 泰子, 安藤哲信, 倉田なお, 日赤薬剤師会「簡 易眯濁法に関するアンケート調查」集計結果 H18.1 とH19.6との比較, 静脈経腸栄養, 2009, 24, 595-598.

4）武藤浩司, 宮川哲也, 古澤洋子, 岡村正夫, 宮本 悦子, 増田修三, 経管栄養施行患者における薬剤 投与方法の課題〜新潟県内の害態調查から〜， 日本静脈経腸栄養学会雑誌, 2015, 30, 1174-1179.

5）阿部かずみ, 在宅でのPEG管理上の問題点とそ の解決法, 静脈経腸栄養, 2008, 23, 243-247.

6) Sakurada W, Shimoyama T, Itoh K, Kobayashi M, Solubility estimation for drugs treated with the simple suspension method using available dissolution test profiles, Jpn J Pharm Health Care Sci, 2015, 41, 540-549.

7）倉田なお 小, 小松千絵, 平藤 彰, 森 義明, 経管 投与可能な固形製剤の検討と一覧表の作成, 医 療薬学, 2001, 27, 461-472.

8）座間味義人, 小山敏広, 合葉哲也, 天野 学, 安藤 哲信, 倉田なおみ, 名和秀起, 名倉弘哲, 北村佳久, 千堂年昭, 粉砕法による経管投与における薬剤 量損失に対する簡易懸濁法の有用性についての 検討, 静脈経腸栄養, 2014, 29, 1027-1033.

9）小林道也, 高倉みなみ, 野田久美子, 櫻田涉, 唯野貢司, 難水溶性薬物の簡易懸濁法施行時に おける先発品と後発品の溶解性の比較, 薬剂学, 2014, 74, 93-98. 